\title{
Microbial Degradation of Poultry Feather Wastes under the Influence of Temperature and pH - A Review
}

\author{
Sayali Kodak, Tanuja Gharge, Vishwajit Chavan and Sibi G* \\ Department of Biotechnology, Indian Academy Degree College-Autonomous, India
}

Submission: August 26, 2019; Published: September 17, 2019

*Corresponding author: Sibi G, Head, Department of Biotechnology, Indian Academy Degree College-Autonomous, Bengaluru, India

\begin{abstract}
Poultry feathers require different approaches of disposal. Feather waste represents a huge resource of protein and the rational utilization of millions of tons of waste feathers will not only ease the shortage of protein resources but will also improves the environment. Conventional methods used for disposing or converting them to protein hydrolysates such as land filling, incineration, burning or the use of chemicals are costly, not environmentally friendly, and pose a danger to living organisms. Microbial hydrolysis is considered an alternative environmentalfriendly method for recycling. As physiological and nutritional factors greatly affect feather degradation and keratinase production, the effects of various factors such as incubation temperature and $\mathrm{pH}$ on feather degradation by various microorganisms were reviewed in this study. Based on the various studies reported earlier involving microorganisms to degrade poultry feather and keratinase production, biodegradation of feathers is found to be an efficient, cost-effective, and environmentally friendly method for bioconversion of feather waste into useful products. The use of keratinolytic microorganisms to degrade poultry feather has emerged as a sustainable and alternative tool to sustainable use of feather waste.
\end{abstract}

Keywords: Poultry feather; Feather waste; Keratin; Keratinase; Biodegradation

\section{Introduction}

The daily consumption of chicken increases annually as one of the cheapest and healthiest sources of protein. About 3 billion pounds of chicken feathers are generated every year in the world with a great percentage disposed as waste [1,2]. Feathers account for approximately $5-7 \%$ of the total weight of a mature chicken and feather waste represents a huge resource of protein. $90 \%$ of feather biomass constitutes primarily $\beta$-keratin, azelon, and insoluble protein extensively cross-linked by disulfide bonds $[3,4], 70 \%$ of amino acids, high-value elements, vitamins, and growth factors [5].

Since each chicken can provide meat, the generation of chicken feather wastes from slaughter and poultry houses will come from different coloured chickens such as white, black, brown and/or multiple-coloured broilers, layers and cockerels. These keratin-rich wastes are considered recalcitrant environmental contaminants and mixture of different coloured feather wastes is often disposed in dumb sites or landfills especially in developing countries. Majority of feathers are discarded or burned as waste, while a small proportion is used in down products and insulation material [6]. Despite the abundance, chicken feathers are more frequently treated as waste and often burned or taken to the landfill, polluting the environment.
Economic pressures, environmental pressures, increasing interest in using renewable and sustainable raw materials, and the need to decrease reliance on non-renewable petroleum resources behove the industry to find better ways of dealing with waste feathers. Burning poultry wastes may actually produce as much or more toxic air emissions than coal plants. Due to poor management, poultry waste especially feathers have become one of the major pollutants due to their recalcitrant nature $[7,8]$. The rational utilization of millions of tons of waste feathers in poultry factories will not only ease the shortage of protein resources but will also improve the environment.

Hydrolysis, reduction, and oxidation methods have been reported to isolate keratin from feather, wool, and hair [9-13]. Nevertheless, a large number of chemical reagents, i.e., urea, sulfite, thiol, acid, and alkali, were used in the extraction processes. However, the conventional methods used for disposing or converting them to protein hydrolysates such as landfilling, incineration, burning or the use of chemicals are costly, not environmentally friendly, and pose a danger to living organisms. Biodegradation of keratin is a process that involves a variety of biological factors and definitive mechanisms. 
An alternative to reduce these environmentally unfavorable disposal options is the utilization of feather constituents as animal feed. Traditional methods to degrade feathers for subsequent use as animal feed include alkali hydrolysis and cooking under steam pressure. For example, the feathers may be hydrolysed, dried and ground to a powder to be used as a feed supplement for a variety of livestock, primarily pigs [14]. This is a fairly expensive process, however, and results in a protein product of low quality for which the demand is low [15]. These methods are not ideal in that they not only destroy the amino acids in the feathers but also consume large amounts of energy. Further, high content of $\beta$-keratin renders chicken feathers insoluble and resistant to intestine digestion by animals unless they are appropriately pretreated [16]. The keratinase produced performs keratinolytic function through breaking down of complex keratin structure of feathers, and subsequent releasing the major amino acids in the keratin, as well as soluble oligopeptides.

The management of feather wastes requires different approaches. The most commonly used method for feather disposal is incineration [17] and degradation by chemical methods. Compared with the physical and chemical treatments that frequently involve highly energy-consuming processes, feather treatments with biological processes are more promising because bioprocesses are advantageous in keeping the valuable nutrient components that are vulnerable to harsh conditions. Microbial hydrolysis is considered an alternative environmental-friendly method for recycling and valorising feathers [18-20]. Microbial processes are not only environmental friendly [21], but also maintain the original structure and activity of the products [22]. Studies on biodegradation are focused on the screening and identification of microorganisms that can degrade feathers. Diverse microbes have been identified as potent feather degraders. A number of feather-degrading microbes such as bacteria, Streptomyces and fungi [23-25] have been isolated from various environmental sources. Protease with keratinase activity produced by growing microbes of certain species decomposes the feathers, releasing the proteins, peptides, and free proteinogenic amino acids (and derivatives) that can support the growth of the living microbes. The products of keratinase hydrolysis of feathers are mainly amino acids and soluble peptides and display antioxidant properties $[26,27]$.

Degradation of feathers is the process of enzymatic degradation of $\beta$-keratin. The destroying of the hard protein by heating facilitates the function of enzymes, leading to more degradation [20]. Keratinase enzymes that have been purified from different microorganisms to date, such as fungi [28,29], bacteria [30,31], and a few Streptomyces species [32,33], all act as proteinases and have a high level of activity on insoluble keratin. Complete feather degradation $(98.3 \pm 1.52 \%)$ with high keratinase production $(373 \pm 4 \mathrm{U} / \mathrm{ml})$ by Bacillus pumilus was observed [34].

As physiological and nutritional factors greatly affect feather degradation and keratinase production, the effects of various factors such as incubation temperature and $\mathrm{pH}$ on feather degradation by various microorganisms were reviewed in this study.

\section{Methodology}

A systematic search was carried out in PubMed, Scopus and Web of Sciences using a combination of Boolean operators. Peer reviewed papers in English on the microbial degradation of poultry feather were retrieved and evaluated based on titles and abstracts. The retrieved papers were managed using Mendeley and the data were consolidated.

\section{Morphological Structure of Feather}

The chicken feather is composed of three distinct units: the rachis, the central shaft of the feather that runs the entire length of the feather to which is attached the secondary structures, the barbs and the tertiary structures, the barbules. The length of the rachis varies depending on the sampling position of the feathers on the body of the chicken; however, the lengths of barbs and barbules do not vary much except that sometimes barbs and barbules at the base of the rachis are longer than those at the tip of the rachis. The lengths of the rachis are about $1-150 \mathrm{~mm}$ and barbs are about $1-45 \mathrm{~mm}$. The barbules are about $1-800 \mathrm{~mm}$ long and have hook-like structures at their tips. Barbs display a fibrillar surface but no scale [35].

Keratin is the insoluble structural protein of feathers and wool and is known for its high stability. The composition and molecular configurations of its constituent amino acids warrant structural rigidity. The keratin chain is tightly packed in the $\alpha$-helix ( $\alpha$-keratin) or $\beta$-sheet ( $\beta$-keratin) into a supercoiled polypeptide chain, resulting in mechanical stability and resistance to common proteolytic enzymes such as pepsin, trypsin, and papain. In addition, cross-linking of protein chains by cysteine bridges confers high mechanical stability and resistance to proteolytic degradation of keratins.

Role of $\mathrm{pH}$ and Temperature on Microbial Feather Degradation

\section{pH}

The increase in $\mathrm{pH}$ during cultivation is an important characteristic accompanying keratin hydrolysis and the keratinolytic potential of micro-organisms. Organisms with a higher keratinolytic activity turn the media more alkaline, in comparison with other organisms exhibiting lower keratinolytic activity [36]. This observation is based on the fact that keratin degradation involves deamination reactions, which result in an increase in $\mathrm{pH}$. Enhanced keratinase activity of $16.15 \mathrm{U} / \mathrm{mL}$ was observed at $\mathrm{pH} 8$ by Alcaligenes sp [37]. The bacterium grew well over a $\mathrm{pH}$ range of $7 \mathrm{e} 9$ using phosphate buffer, while high keratinase production was limited to $\mathrm{pH}$ 7.5-8.5 with 96\% feather degradation. Sangali \& Brandelli [38] reported that keratinase production was higher at $\mathrm{pH} 6.0$. 
The optimum $\mathrm{pH}$ of 7.8 for keratinase production by various fungi such as Scopulariopsis brevicaulis [39], Microsproum canis [40], Doratomyces microsporus and Paecilomyces marquandii $[41,42]$ was reported earlier. Farag \& Hassan [28] reported the purification and characterization of a keratinase secreted by Aspergillus oryzae. The effect of immobilization on the obtained enzyme was also taken into consideration and maximum keratinolytic activity of free enzyme was observed between pHs 7 and 9 with an optimum at pH 8.0 and the optimum $\mathrm{pH}$ of the immobilized enzyme was 7.4. The optimal conditions for keratinase production using chicken feather include initial $\mathrm{pH}$ of 7.0 , inoculum size of $2 \%(\mathrm{v} / \mathrm{v})$, and cultivation at $40^{\circ} \mathrm{C}$ by Bacillus weihenstephanensis [43].

Kojima et al. [44] had isolated the feather-degrading Bacillus pseudofirmus FA30-01 from the soil sample of poultry farm. The isolate completely degraded feather pieces after liquid culture at $30^{\circ} \mathrm{C}(\mathrm{pH} 10.5)$ for 3 days. In another study, maximum feather-degrading activity by Chryseobacterium sp. was observed at $\mathrm{pH} 8.0$ and $25^{\circ} \mathrm{C}[45]$.

\section{Temperature}

The interaction between temperature and feather degradation was studied by Demir et al. [25]. Keratinase activity was dependent on the temperature. For example, lowest keratinase activity $(8.03 \mathrm{U} / \mathrm{ml})$ was with the lowest temperature condition $\left(15^{\circ} \mathrm{C}\right)$ and the highest activity $(405.5 \mathrm{U} / \mathrm{ml})$ was a thighest temperature $\left(27.5^{\circ} \mathrm{C}\right)$. Similar observations were reported previously with other bacteria [46-48] describing of the effect of temperature on the keratinase production. The growth, feather degrada- tion, and keratinase production of Alcaligenes sp. were optimal within a room temperature range of $25-30^{\circ} \mathrm{C}$ [37]. The maximum enzyme production was observed by growing Vibrio sp at $30^{\circ} \mathrm{C}$, although similar levels were observed at $25^{\circ} \mathrm{C}$ [38]. Anbu et al. [47] demonstrated that the keratinase produced by Trichophyton sp. was able to actively degrade the chicken feather as substrate. They found that highest enzyme production by Trichophyton was registered at $35^{\circ} \mathrm{C}(5.0 \mathrm{KU} / \mathrm{ml})$ and there was a decline in enzyme production beyond $35^{\circ} \mathrm{C}$.

Keratinase from Kocuria rosea was active at a broad range of temperature $\left(25-55^{\circ} \mathrm{C}\right)$ with an optimum of $40^{\circ} \mathrm{C}$. The enzyme remained fully active when tested at temperatures between 10 and $60^{\circ} \mathrm{C}$ for $1 \mathrm{~h}$; additionally, at $90^{\circ} \mathrm{C}$ the enzyme was $40 \%$ active [31]. Disintegration of whole chicken feathers by incubation with keratinase from Streptomyces pactum was optimal in the range of 40 to $70^{\circ} \mathrm{C}$ [32]. The complete degradation of feather by Bacillus licheniformis was observed in the feather-peptone medium within $24 \mathrm{~h}$ at $37^{\circ} \mathrm{C}$ [4]. Fervidobacterium islandicum showed the highest keratinolytic activity and degraded native chicken feathers completely at $70^{\circ} \mathrm{C}$ within $48 \mathrm{~h}$ [49]. The effects of initial $\mathrm{pH}$ and temperature on feather degradation by $B$. subtilis were investigated [50]. An optimum effect at $37^{\circ} \mathrm{C}$ and $\mathrm{pH} 8.5$ in a basal feather medium was found in the degradation process. Bacillus licheniformis from a polluted river exhibited high proteinase production when grown in chicken-feather media. Complete feather degradation was achieved at $37^{\circ} \mathrm{C}$ after $48 \mathrm{hrs}$ [51]. Werlang \& Brandelli [52] reported that the temperature of $30-37^{\circ} \mathrm{C}$ was optimum for feather-degrading activity by Bacillus sp (Table 1-3).

Table 1: Bacterial degradation of Poultry Feather and Keratinase Production.

\begin{tabular}{|c|c|c|c|c|c|}
\hline Organism & Temperature & pH & Keratinase Yield & Time & Reference \\
\hline Vibrio sp strain kr2 & $30^{\circ} \mathrm{C}$ & 6 & $32 \mathrm{U} / \mathrm{ml}$ & $72 \mathrm{hrs}$ & {$[38]$} \\
\hline Xanthomonas maltophilia & & & & & [53] \\
\hline Fervidobacterium islandicum & $70^{\circ} \mathrm{C}$ & 7 & $13 \mathrm{U} / \mathrm{mL}$ & $48 \mathrm{hrs}$ & [49] \\
\hline Bacillus licheniformis & $47^{\circ} \mathrm{C}$ & 7 & & & [7] \\
\hline Chryseobacterium sp. kr6 & $25^{\circ} \mathrm{C}$ & 8 & & & {$[45]$} \\
\hline Microbacterium & $30^{\circ} \mathrm{C}$ & 7 & $43 \mathrm{U} / \mathrm{ml}$ & & {$[46]$} \\
\hline Bacillus subtilis & $37^{\circ} \mathrm{C}$ & 8.5 & & & {$[50]$} \\
\hline Bacillus licheniformis & $37^{\circ} \mathrm{C}$ & & & $24 \mathrm{hrs}$ & {$[4]$} \\
\hline Kocuria rosea & $40^{\circ} \mathrm{C}$ & 10 & & & {$[31]$} \\
\hline Bacillus pseudofirmus & $35^{\circ} \mathrm{C}$ & 10.5 & & 3 days & {$[44]$} \\
\hline Bacillus licheniformis & $37^{\circ} \mathrm{C}$ & & $37.35 \mathrm{U} / \mathrm{mL}$ & $48 \mathrm{hrs}$ & {$[51]$} \\
\hline Bacillus megaterium & $25-40^{\circ} \mathrm{C}$ & $7-11$ & $468 \mathrm{U} / \mathrm{mL}$ & 7 days & [14] \\
\hline Bacillus subtilis & $30^{\circ} \mathrm{C}$ & 8 & $53.3 \mathrm{U} / \mathrm{mL}$ & 4 days & {$[54]$} \\
\hline Bacillus weihenstephanensis & $40^{\circ} \mathrm{C}$ & 7 & & & [43] \\
\hline Bacillus sp MKR5 & $40^{\circ} \mathrm{C}$ & 8 & $100 \%$ & & {$[24]$} \\
\hline Nocardiopsis sp. SD5 & $45-50^{\circ} \mathrm{C}$ & 9 & $64.6 \mathrm{U} / \mathrm{mL}$ & 4 days & {$[55]$} \\
\hline Alcaligenes sp.AQ05-001 & $27^{\circ} \mathrm{C}$ & 8 & $88.4 \mathrm{U} / \mathrm{ml}$ & $72 \mathrm{hrs}$ & [49] \\
\hline
\end{tabular}


International Journal of Environmental Sciences \& Natural Resources

\begin{tabular}{|c|c|c|c|c|c|}
\hline Bacillus sp MBRL 575 & $30^{\circ} \mathrm{C}$ & & $305 \mathrm{U} / \mathrm{ml}$ & {$[56]$} \\
\hline Bacillus pumilus & $37^{\circ} \mathrm{C}$ & 10 & $373 \mathrm{U} / \mathrm{ml}$ & {$[34]$} \\
\hline Bacillus licheniformis & $42^{\circ} \mathrm{C}$ & 6 & $72.4 \mathrm{U} / \mathrm{ml}$ & {$[58]$} \\
\hline Bacillus aerius & $35^{\circ} \mathrm{C}$ & 7.5 & $127.63 \mathrm{U} / \mathrm{ml}$ & {$[18]$} \\
\hline Micrococcus luteus & & & $32.3 \mathrm{U} / \mathrm{mL}$ & 15 days & $168 \mathrm{hrs}$ \\
\hline Pseudochrobactrum IY-BUK1 & $30^{\circ} \mathrm{C}$ & 7.5 & $95.25 \mathrm{U} / \mathrm{ml}$ & {$[57]$} & {$[60]$} \\
\hline Bacillus paralicheniformis & & & & $96 \mathrm{hrs}$ & {$[61]$} \\
\hline Bacillus licheniformis & $35^{\circ} \mathrm{C}$ & & & $96 \mathrm{hrs}$ & {$[61]$} \\
\hline Stenotrophomonas maltophilia & $23^{\circ} \mathrm{C}$ & & & & \\
\hline
\end{tabular}

Table 2: Fungal degradation of Poultry Feather and Keratinase Production

\begin{tabular}{|c|c|c|c|c|c|}
\hline Organism & Temperature & pH & Keratinase Yield & Time & Reference \\
\hline Aspergillus niger & $50^{\circ} \mathrm{C}$ & 8 & $71.43 \mathrm{U} / \mathrm{ml}$ & & {$[28]$} \\
\hline Beauveria bassiana & & $6.0-8.2$ & $62.8 \mathrm{U} / \mathrm{ml}$ & 4-6 days & [66] \\
\hline Alternaria tenuissima & $25-28^{\circ} \mathrm{C}$ & 6.5 & $53.8 \mathrm{U} / \mathrm{mL}$ & & [66] \\
\hline Beauveria bassiana & $25-28^{\circ} \mathrm{C}$ & 6.5 & $62.8 \mathrm{U} / \mathrm{ml}$ & & [66] \\
\hline Curvularia brachyspora & $25-28^{\circ} \mathrm{C}$ & 6.5 & $55.4 \mathrm{U} / \mathrm{ml}$ & & [66] \\
\hline Trichophyton & $35^{\circ} \mathrm{C}$ & 8 & $4.6 \mathrm{U} / \mathrm{ml}$ & 5 weeks & {$[47]$} \\
\hline Myrothecium verrucaria & $37^{\circ} \mathrm{C}$ & 8.3 & & & {$[62]$} \\
\hline Microsporum fulvum & $30^{\circ} \mathrm{C}$ & 6.5 & & & [63] \\
\hline Aspergillus fumigates & NR & 8.5 & & & {$[25]$} \\
\hline Aphanoascus fulvescens & $28.7^{\circ} \mathrm{C}$ & 7.58 & & & [64] \\
\hline
\end{tabular}

Table 3: Degradation of Poultry Feather and Keratinase Production by Actinomycetes.

\begin{tabular}{|c|c|c|c|c|c|}
\hline Organism & Temperature & $\mathbf{p H}$ & Keratinase Yield & Time & Reference \\
\hline Sreptomyces fradiae & $60^{\circ} \mathrm{C}$ & 8 & & $0.5 \mathrm{hrs}$ & {$[65]$} \\
\hline Streptomyces sp 2M21 & $27.5^{\circ} \mathrm{C}$ & 8 & $405.5 \mathrm{U} / \mathrm{ml}$ & 5.5 days & {$[23]$} \\
\hline
\end{tabular}

\section{Conclusion}

Due to poor management, poultry waste especially feathers have become one of the major pollutants. Traditional feather degradation reduces the overall quality of proteins and destroys essential amino acids. Biodegradation of feathers is found to be an efficient, cost-effective, and environmental friendly method for bioconversion of feather waste into useful products. The use of keratinolytic microorganisms to degrade poultry feather has emerged as a sustainable and alternative tool to meet this challenge.

\section{References}

1. Isarankura Na Ayutthaya S, Tanpichai S, Wootthikanokkhan J (2015) Keratin extracted from chicken feather waste: extraction, preparation, and structural characterization of the keratin and keratin/biopolymer films and electrospuns. Journal of Polymers and the Environment 23(4): 506-516.

2. Wang J, Hao S, Luo T, Yang Q Wang B (2016) Development of feather keratin nanoparticles and investigation of their hemostatic efficacy. Mater Sci Eng C Mater Biol Appl 68: 768-773.

3. Onifade AA, Al-Sane NA, Al-Musallam AA, Al-Zarban S (1998) Potentials for biotechnological applications of keratin-degrading microorganisms and their enzymes for nutritional improvement of feathers and other keratins as livestock feed resources. Bioresource Technology 66(1): 1-11.

4. Ramnani P, Singh R, Gupta R (2005) Keratinolytic potential of Bacillus licheniformis RG1: structural and biochemical mechanism of feather degradation. Can J Microbiol 51(3): 191-196

5. Grazziotin A, Pimentel FA, Evde J, Brandelli A (2006) Nutritional improvement of feather protein by treatment with microbial keratinase. Animal Feed Science Technology 126(1-2): 135-144.

6. Sharma S, Gupta A, Sharma S, Gupta A (2016) Sustainable management of keratin waste biomass: applications and future perspectives. Brazilian Archives of Biology and Technology 59: 1-14.

7. Manczinger L, Rozs M, Vágvölgyi C, Kevei F (2003) Isolation and characterization of a new keratinolytic Bacillus licheniformis strain. World Journal of Microbiology Biotechnology 19(1): 35-39.

8. Khardenavis AA, Kapley A, Purohit HJ (2009) Processing of poultry feathers by alkaline keratin hydrolyzing enzyme from Serratia sp. 1383. Waste Manag 29(4): 1409-1415

9. Aluigi A, Zoccola M, Vineis C, Tonin C, Ferrero F, et al. (2007) Study on the structure and properties of wool keratin regenerated from formic acid. Int J Biol Macromol 41(3): 266-273.

10. Jin X, Wang Y, Yuan J, Shen J (2016) Extraction, characterization, and NO release potential of keratin from human hair. Materials Letters 175: $188-190$. 
11. Poole AJ, Church JS (2015) The effects of physical and chemical treatments on $\mathrm{Na}_{2} \mathrm{~S}$ produced feather keratin films. Int J Biol Macromol 73: 99-108.

12. Xu H, Yang Y (2014) Controlled de-cross-linking and disentanglement of feather keratin for fiber preparation via a novel process. ACS Sustainable Chemistry and Engineering 2(6): 1404-1410

13. Zhang Y, Zhao W, Yang R (2015) Steam flash explosion assisted dissolution of keratin from feathers. ACS Sustainable Chemistry and Engineering 3(9): 2036-2042.

14. Park SK, Bae D, Hettiarachchy N (2000) Protein concentrate and adhesives from meat and bone meal. J Am Oil Chemists' Society 77(11): 1223-1227.

15. Veerabadran V, Balasundari SN, Devi DM, Kumar DM (2012) Optimisation and production of proteinacious chicken feather fertilizer by proteolytic activity of Bacillus sp. MPTK 6. Indian Journal of Innovations and Developments 1(3): 193-198.

16. Kim WK, Lorenz ES, Patterson PH (2002) Effect of enzymatic and chemical treatments on feather solubility and digestibility. Poultry Science 81(1): 95-98.

17. Papadopoulos MC, El Boushy AR, Roodbeen AE, Ketelaars EH (1986) Effects of processing time and moisture content on amino acid composition and nitrogen characteristics of feather meal. Animal Feed Science Technology 14(3-4): 279-290.

18. Calin M, Constantinescu-Aruxandei D, Alexandrescu E, Răut I, Doni MB, et al. (2017) Degradation of keratin substrates by keratinolytic fungi. Electronic Journal of Biotechnology 28: 101-112.

19. Bhari R, Kaur M, Singh RS, Pandey A, Larroche C (2018) Bioconversion of chicken feathers by Bacillus aerius NSMk2: a potential approach in poultry waste management. Bioresource Technology Report 3: 224-230.

20. Wang T, Liang C, Sun Y, Gao W, Luo X, et al. (2018) Strategical isolation of efficient chicken feather- degrading bacterial strains from tea plantation soil sample. International Microbiology 22(2): 227-237.

21. Fang Z, Zhang J, Du G, Chen J (2017) Rational protein engineering approaches to further improve the keratinolytic activity and thermostability of engineered keratinase KerSMD. Biochemical Engineering Journal 127: 147-153.

22. Daroit DJ, Brandelli A (2014) A current assessment on the production of bacterial keratinases. Critical Reviews in Biotechnology 34(4): 372-384.

23. Demir T, Hames EE, Oncel SS, Vardar-Sukan F (2015) An optimization approach to scale up keratinase production by Streptomyces sp. 2 M21 by utilizing chicken feather. International Biodeterioration and Biodegredation 103: 134-140.

24. Ghasemi Y, Shahbazi M, Rasoul-Amini S, Kargar M, Safari A, et al. (2012) Identification and characterization of feather degrading bacteria from keratin-rich wastes. Annals of Microbiology 62(2): 737-744.

25. Sivakumar N, Raveendran S (2015) Keratin degradation by bacteria and fungi isolated from a poultry farm and plumage. Br Poult Sci 56(2): 210-217.

26. Adriane G, Pimentel FA, Sidnei S, Jong EV, De Adriano B (2007) Production of feather protein hydrolysate by keratinolytic bacterium Vibrio sp. kr2. Bioresour Technol 98(16): 3172-3175.

27. Wan MY, Dong G, Yang BQ, Feng H (2015) Identification and characterization of a novel antioxidant peptide from feather keratin hydrolysate. Biotechnol Lett 38(4): 643-649.

28. Farag AM, Hassan MA (2004) Purification, characterization and immobilization of a keratinase from Aspergillus oryzae. Enzyme and Microbial Technology 34(2): 85-93.
29. Gradisar H, Friedrich J, Krizaj I, Jerala R (2005) Similarities and specificities of fungal keratinolytic proteases: comparison of keratinases of Paecilomyces marquandii and Doratomyces microsporus to some known proteases. Applied and Environmental Microbiology 71(7): 3420-3426.

30. Cheng SW, Hu HM, Shen SW (1995) Production and characterization of keratinase of a feather degrading Bacillus licheniformis PWD-1. Bioscience Biotechnology and Biochemistry 59(12): 2239-2243.

31. Bernal C, Cairo J, Coello N (2006) Purification and characterization of a novel exocellular keratinase from Kocuria rosea. Enzyme and Microbial Technology 38(1-2): 49-54.

32. Bockle B, Galunsky B, Muller R (1995) Characterization of a keratinolytic serine proteinase from Streptomyces pactum DSM 40530. Appl Environ Microbiol 61(10): 3705-3710.

33. Bressollier P, Letourneau F, Urdaci M, Verneuil B (1999) Purification and characterization of a keratinolytic serine proteinase from Streptomyces albidoflavus. Appl Environ Microbiol 65(6): 2570-2576.

34. Ramakrishna Reddy M, Sathi Reddy K, Ranjita Chouhan Y, Bee H, Reddy G (2017) Effective feather degradation and keratinase production by Bacillus pumilus GRK for its application as biodetergent additive. Bioresour Technol 243: 254-263.

35. Tesfaye T, Sithole B, Ramjugernath D, Chunilall V (2017) Valorisation of chicken feathers: Characterization of physical properties and morphological structure. Journal of Cleaner Production 149: 349-365.

36. Kaul S, Sumbali G (1999) Production of extracellular keratinases by keratinophilic fungal species inhabiting feathers of living poultry birds (Gallus domesticus): A comparison. Mycopathologia 146(1): 19-24.

37. Yusuf I, Ahmad SA, Phang LY, Syed MA, Shamaan NA, et al. (2016) Keratinase production and biodegradation of polluted secondary chicken feather wastes by a newly isolated multi heavy metal tolerant bacterium-Alcaligenes sp. AQ05-001. Environmental Management 183: $182-195$

38. Sangali S, Brandelli A (2000) Feather keratin hydrolysis by a Vibrio sp kr2 strain. J Appl Microbiol 89(5): 735-743.

39. Malviya HK, Rajak RC, Hasija SK (1992) Purification and partial characterization of two extracellular keratinases of Scopulariopsis brevicaulis. Mycopathologia 119(3): 161-165.

40. Brouta F, Descamps F, Fett T, Losson B, Gerday C, et al. (2001) Purification and characterization of a $43.5 \mathrm{kDa}$ keratinolytic metalloprotease from Microsporum canis. Medical Mycology 39(3): 269-275.

41. Gradisar H, Kern S, Friedrich J (2000) Keratinase of Doratomyces microsporus. Appl Microbiol Biotechnol 53(2): 196-200.

42. Gradisar H, Friedrich J, Krizaj I, Jerala R (2005) Similarities and specificities of fungal keratinolytic proteases: comparison of keratinases of Paecilomyces marquandii and Doratomyces microsporus to some known proteases. Applied and Environmental Microbiology 71(7): 3420-3426.

43. Sahoo DK, Das A, Thatoi H, Mondal KC, Mohapatra PKD (2012) Keratinase production and biodegradation of whole chicken feather keratin by a newly isolated bacterium under submerged fermentation. Applied Biochemistry and Biotechnology 167(5): 10401051.

44. Kojima M, Kanai M, Tominaga M, Kitazume S, Inoue A, et al. (2006) Isolation and characterization of a feather-degrading enzyme from Bacillus pseudofirmus FA30-01. Extremophiles 10(3): 229-235.

45. Riffel A, Lucas F, Heeb P, Brandelli A (2003) Characterization of a new keratinolytic bacterium that completely degrades native feather keratin. Archives of Microbiology 179(4): 258-265. 
46. Thys RCS, Lucas FS, Riffel A, Heeb P, Brandelli A (2004) Characterization of a protease of a feather-degrading Microbacterium species. Letters in Applied Microbiology 39(2): 181-186.

47. Anbu P, Hilda A, Sur HW, Hur BK, Jayanthi S (2008) Extracellular keratinase from Trichophyton sp. HA-2 isolated from feather dumping soil. International Biodeterioration and Biodegredation 62(3): 287292.

48. Casarin F, Cladera-Olivera F, Brandelli A (2008) Use of poultry byproduct for production of keratinolytic enzymes. Food and Bioprocess Technology 1(3): 301-305.

49. Nam GW, Lee DW, Lee HS, Lee NJ, Kim BC, et al (2002) Native-feather degradation by Fervidobacterium islandicum AW-1, a newly isolated keratinase-producing thermophilic anaerobe. Arch Microbiol 178(6): 538-547.

50. Liu Q, Zhang T, Song N, Li Q, Wang Z, et al. (2014) Purification and characterization of four key enzymes from a feather-degrading Bacillus subtilis from the gut of tarantula Chilobrachys guangxiensis. International Biodeterioration and Biodegradation 96: 26-32.

51. Fakhfakh N, Kanoun S, Manni L, Nasr M (2009) Production and biochemical and molecular characterization of a keratinolytic serine protease from chicken feather-degrading Bacillus licheniformis RPk. Canadian Journal of Microbiology 55(4): 427-436.

52. Werlang PO, Brandelli A (2005) Characterization of a novel featherdegrading Bacillus sp. Strain. Appl Biochem Biotechnol 120(1): 71-80.

53. De Toni CH, Richter MF, Chagas JR, Henriques JA, Termignoni C (2002) Purification and characterization of an alkaline serine endopeptidase from a feather-degrading Xanthomonas maltophilia strain. Can J Microbiol 48(4): 342-348.

54. Jeong JH, Jeon YD, Lee OM, Kim JD, Lee NR, et al. (2010) Characterization of a multifunctional feather-degrading Bacillus subtilis isolated from forest soil. Biodegradation 21(6): 10291040 .

55. Saha S, Dhanasekaran D, Shanmugapriya S, Latha S (2012) Nocardiopsis sp. SD5: A potent feather degrading rare actinobacterium isolated from feather waste in Tamil Nadu, India. J Basic Microbiology 53: 608-616.

56. Kshetri P, Ningthoujam, DS (2016). Keratinolytic activities of alkaliphilic Bacillus sp. MBRL 575 from a novel habitat, limestone deposit site in Manipur, India. Springer Plus 5(595).
57. Yusuf I, Garba L, Shehu MA, Oyiza AM, Kabir MR, et al. (2019) Selective biodegradation of recalcitrant black chicken feathers by a newly isolated thermotolerant bacterium Pseudochrobactrum sp. IY-BUK1 for enhanced production of keratinase and protein-rich hydrolysates. International Microbiology, pp. 1-12.

58. Abdel-Fattah AM, El-Gamal MS, Ismail SA, Emran MA, Hashem AM (2018) Biodegradation of feather waste by keratinase produced from newly isolated Bacillus licheniformis ALW1. J Genet Eng Biotechnol 16(2): 311-318.

59. Laba W, Choinska A, Rodziewicz A, Piegza M (2015) Keratinolytic abilities of Micrococcus luteus from poultry waste. Braz J Microbiol 46(3): 691-700.

60. Santha Kalaikumari S, Vennila T, Monika V, Chandra Raj K, Gunasekaran P, et al. (2018) Bioutilization of poultry feather for keratinase production and its application in leather industry. Journal of Cleaner Production 208: 44-53.

61. Peng Z, Mao X, Zhang J, Du G, Chen J (2019) Effective biodegradation of chicken feather waste by co-cultivation of keratinase producing strains. Microbial Cell Factories 18(84).

62. Moreira-Gasparin FG, de Souza CGM, Costa AM, Alexandrino AM, Bracht CK, et al. (2009) Purification and characterization of an efficient poultry feather degrading-protease from Myrothecium verrucaria. Biodegradation 20(5): 727-736.

63. Darah I, Nur-Diyana A, Nurul-Husna S, Jain K, Lim SH (2013) Microsporum fulvum IBRL SD3: As Novel Isolate for Chicken Feathers Degradation. Appl Biochem Biotechnol 171(7): 1900-1910.

64. Bohacz J (2017) Biodegradation of feather waste keratin by a keratinolytic soil fungus of the genus Chrysosporium and statistical optimization of feather mass loss. World J Microbiol Biotechnol 33(1): 13.

65. Young RA, Smith RE (1975) Degradation of feather keratin by culture filtrates of Streptomyces fradiae. Canadian Journal of Microbiolog. 21(5): 583-586.

66. Marcondes NR, Taira CL, Vandresen DC, Svidzinski TIE, Kadowaki MK, et al. (2007) New Feather-Degrading Filamentous Fungi. Microb Ecol 56(1): 13-17. 